\title{
INTERAKSI EDUKATIF DALAM AL-QUR`AN
}

\author{
Alimuddin \\ Dosen Program Studi Manajemen Pendidikan Islam Institut Agama Islam Negeri (IAIN) \\ Palopo Jl. Agatis Balandai, Kota Palopo Indonesia \\ E-Mail : alimuddin@iainpalopo.ac.id
}

\begin{abstract}
Abstrak
Penelitian ini bertujuan untuk menganalisis konsep interaksi edukatif dalam al-Qur`an yang mengkaji secara khusus surah al-Baqarah (2) ayat 133 dan surah al-Saffat (37) ayat 102. Penelitian ini menggunakan pendekatan penelitian kualitatif dan menggunakan jenis penelitian studi pustaka (Library Research). Teknik pengumpulan data dilakukan dengan menggunakan teknik dokumentasi. Data yang terkumpul dianalisis dengan menggunakan metode analisis isi (Content Analysis Method). Hasil penelitian menunjukan bahwa interaksi edukatif dalam al-Qur`an memiliki tujuan menciptakan generasi yang bertauhid kepada Allah, rajin beribadah, dan berakhlak yang mulia. Ketercapaian tujuan itu dipengaruhi oleh kepribadian seorang pendidik yang sabar, penyayang, dan mengetahui kondisi psikologis murid. Interaksi edukatif dalam al-Qur`an merupakan jembatan penghubung antara hati/nilai (velues), pengetahuan (knoeledge), dan perbuatan (behavior) yang mengantarkan peserta didik menjadi sosok yang tercerahkan, mampu membangun mindset, yaitu pola pikir ilmiah dan memiliki karakter yang mulia.
\end{abstract}

Kata Kunci: Interaksi, Edukatif, Al-Qur’an.

\begin{abstract}
This research aims at analysing the interactive education concept in Qur'an wich examines specifically surah al-Baqarah (2) verse 133 and surah al-Saffat (37) verse 102. This research applied both qualitative research approach and are uses type of research literature (Library Research). The technique of data collection carried out in this Reseach was decomentation techniques. Furthermore, the collected data was analysed by using the content Analysis Method. The finding shows that educative interaction in the koran has purposes of promoting a generation of monotheism (Tauhid) to Allah, diligent in worship, and noble character. The achievement is significantly influenced by the personality influenced by the personality of an educator who is patient, caring, and knows the students' psychology. Moreover, an educative interaction within Qur'an to correspond between values, knowledge and behavior wich lead the learners to be great figures, being able to build a mindset namely scientific thought and noble character.
\end{abstract}

Keywords: Interaction, Educative, Al-Qur'an. 


\section{PENDAHULUAN}

Pendidikan dalam konteks yang luas mencakup seluruh proses hidup dan segenap bentuk interaksi individu dengan lingkungannya, baik secara formal maupun nonformal, dalam rangka mewujudkan dirinya sesuai dengan tahapan tugas perkembangannya secara optimal sehingga mencapai taraf kedewasaan tertentu. ${ }^{1}$ Dengan demikian keluarga, masyarakat, dan sekolah merupakan sarana pendidikan yang memberikan pengaruh yang besar dalam tahapan perkembangan kedewasaan sekaligus faktor utama dalam mewujudkan tujuan pendidikan.

Sedangkan dalam konteks yang sempit, pendidikan merupakan salah satu proses interaksi belajar mengajar dalam bentuk formal yang dikenal sebagai pengajaran (instructional). ${ }^{2}$ Dalam proses interaksi belajar mengajar ini guru dan peserta didik saling berinteraksi satu dengan yang lainnya guna untuk membentuk kepribadian peserta didik menjadi manusia yang dicitacitakan sebagaimana yang termuat dalam tujuan pendidikan.

Interaksi antara pendidik dan peserta didik memiliki tujuan yang sama yaitu pembelajaran. Dalam proses pembelajaran terjadi hubungan antara pendidik dan peserta didik yang saling mempengaruhi satu dengan yang lainnya. Pendidik merupakan seseorang yang memberikan pengaruh kepada peserata didik dalam proses pembelajaran. Dan peserta didik merupakan istilah yang menekankan pentingnya murid berpartisipasi dalam proses pembelajaran. ${ }^{3}$

Unsur paling vital dalam proses belajar mengajar adalah pendidik (guru) dan peserta didik (murid). Seluruh kegiatan belajar mengajar selalu melibatkan pendidik dan peserta didik sebagai pelaksana. Pendidik dan peserta didik terikat oleh suatu hubungan timbal balik baik secara langsung maupun tidak langsung demi mencapai tujuan kegiatan. Hubungan timbal balik ini menentukan berhasil atau tidak berhasilnya kegiatan belajar mengajar yang ditandai dengan adanya pemahaman peserta didik terkait dengan kemampuan pribadi, baik pada ranah kognitif, afektif, dan psikomotorik. Interaksi guru dan siswa merupakan faktor yang sangat penting dalam mencapai tujuan pendidikan. Hal ini dikarenakan di dalam proses belajar mengajar terjadi interkasi antara guru dan siswa dan begitupun dengan sebaliknya. Guru memberikan pelajaran sedangkan murid menerima pelajaran. Interaksi yang efektif antara guru dan murid akan mempermudah peserta didik menerima dan memahami pelajaran dengan baik.

\footnotetext{
1 Makmun. Psikologi Kependidikan Perangkat Sistem Pengajaran Modul. Bandung. PT. Remaja Rosdakarya. 2004, hal. 22.

2 Ibid., hal. 23.

3 Ahmad Tafsir. Filsafat Pendidikan Islami: Integrasi Jasmani, Rohani, dan Kalbu Memanusiakan Manusia. Bandung. PT. Remaja Rosda Karya. 2008, hal 165.
} 
Pelaksanaan proses belajar mengajar antara guru dan murid seringkali terjadi sekedar melakukan proses trasnfer of knowledge. Guru hanya menyampaikan bahan ajar yang telah disiapkan kepada siswa tanpa mempertimbangkan aspek-aspek lain yang dapat menunjang tercapainya hasil belajar yang diinginkan. Hal inilah yang menjadi salah satu faktor yang mengakibatkan proses belajar tidak maksimal. Interaksi edukatif merupakan interaksi yang sarat dengan nilai, dan nilai itulah yang diinternalisasikan melalui proses pendidikan terutama oleh guru kepada muridnya. ${ }^{4}$ Seorang guru harus memiliki kepribadian yang mulia agar dapat diteladani oleh anak didik. Dengan demikian nilai-nilai yang diinternalisasikan ke dalam diri anak didik melalui proses interaksi dapat dilakukan dengan baik.

Dalam perspektif Islam, al-Qur`an menceritakan beberapa kisah yang menggambarkan proses interaksi edukatif sebagaimana yang terdapat dalam al-Qur`an surah al-Baqarah (2) ayat 133, dan surah al-Saffat (37) ayat 102. Dalam surah al-Baqarah (2) ayat 133 tersebut, Allah SWT., menceritakan kisah Nabi Ya kub dalam mengajarkan agama yang benar kepada anaknya. Kisah tersebut merupakan sebuah proses interaksi edukatif nabi Ya`kub terhadap anaknya. Dalam surah al-Saffat (37) ayat 102 dikisahkan mengenai interaksi edukatif Nabi Ibrahim as dengan anaknya Ismail ketika Allah memerintahkan untuk menyembelih anaknya (Ismail). Interaksi edukatif dalam ayat al-Qur`an ini menjadi sangat menarik untuk dikaji lebih mendalam.

\section{KERANGKA TEORI}

Interaksi edukatif adalah interaksi yang berlangsung dalam suatu ikatan untuk melaksanakan tujuan pendidikan dan pengajaran atau lebih dikenal dengan interkasi belajar mengajar. Interkasi belajar mengajar mengandung suatu arti adanya kegiatan interaksi dari tenaga pengajar yang melaksanakan tugas mengajar dan adanya anak didik sebagai peserta belajar, dimana dalam interkasi itu pengajar memberikan dan mengembangkan motivasi kepada siswa agar dapat melakukan kegiatan belajar mengajar secara optimal. 5 Djamarah mengemukakan bahwa, Interaksi edukatif adalah interaksi yang bernilai pendidikan, yaitu interaksi yang dengan sadar meletakkan tujuan untuk mengubah tingkah laku dan perbuatan seseorang. ${ }^{6}$

Sardiman mengemukakan bahwa interaksi dapat dikatakan sebagai interaksi edukatif, apabila secara sadar mempunyai tujuan untuk mendidik,

4 Tobroni. Pendidikan Islam: Paradigma Teologis, Filosofis, dan Spiritualitas. Malang. UMM Press. 2008, hal, 144.

${ }^{5}$ Sardiman. Interaksi dan Motivasi Belajar Mengajar. Jakarta. PT. Raja Grafindo Persada. 2007, hal. 1-2.

${ }^{6}$ Djamarah. Guru dan Anak Didik dalam Interaksi Edukatif. Jakarta. PT. Rinneka Cipta. 2000, hal. 11. 
untuk mengantarkan anak didik ke arah kedewasaannya. ${ }^{7}$ Lebih lanjut mengemukakan bahwa suatu interaksi dikatakan memiliki nilai edukatif bukan semata-mata ditentukan oleh bentuk-bentuknya atau materi yang diajarkan, melainkan lebih pada tercapai atau tidaknya tujuan interaksi edukatif itu sendiri. ${ }^{8}$ Umar Tirtarahadja mengatakan bahwa interaksi edukatif merupakan komunikasi timbal balik antarpeserta didik dengan pendidik yang terarah kepada tujuan pendidikan. ${ }^{9}$

Pendidikan dalam rumusan normatif merupakan usaha pembentukan manusia yang bertanggung jawab, bersusila dan demokratis. Sedangkan peristiwa atau proses interaksi pendidikannya adalah suatu proses teknis. Proses teknis ini merupakan gambaran berlangsungnya proses belajarmengajar. Belajar mengajar adalah suatu proses yang dilakukan dengan sadar dan bertujuan. Tujuan merupakan pedoman ke arah mana proses belajar itu diarahkan. Proses belajar mengajar akan berhasil bila hasilnya mampu membawa perubahan dalam pengetahuan, pemahaman, keterampilan, dan sikap dalam diri anak didik. ${ }^{10}$

\section{Interaksi Edukatif sebagai Proses Pendidikan Nilai}

Interaksi edukatif adalah interaksi yang sarat dengan nilai, dan nilai itulah yang hendak diinternalisasikan melalui proses pendidikan terutama oleh guru kepada muridnya. ${ }^{11}$ Dengan demikian maka interaksi edukatif tidak terjadi tanpa adanya nilai-nilai yang terkandung di dalamnya. Proses belajar mengajar merupakan proses penanaman nilai-nilai dari guru ke siswa. Interaksi edukatif merupakan jembatan penghubung antara hati nilai (velues), pengetahuan (knoeledge), dan perbuatan (behavior) yang mengantarkan kepada pola tingkah laku sesuai dengan nilai dan perbuatan yang diterima oleh anak didik. ${ }^{12}$

Sebagai interaksi yang sarat akan nilai, maka dalam proses interkasi edukatif mengandung tiga unsur pokok yaitu: ${ }^{13}$

1. Heart, yang meliputi keyakinan dasar (core belief) dan nilai-nilai dasar (core values).

Dalam interaksi edukatif, tugas guru (terutama bagi guru agama) bukan hanya mengajarkan tentang pengetahuan agama seperti pengetahuan tentang keimanan, pengetahuan tentang baik dan buruk, pengetahuan tentang ritual

${ }^{7}$ Sardiman. $O p$, cit., hal. 8.

8 Tobroni. Pendidikan Islam: Paradigma Teologis, Filosofis, dan Spiritualitas. Malang. UMM Press. 2008, hal. 144.

${ }^{9}$ Umar Tirtaraharja. Pengantar Pendidikan. Jakarta. PT. Rinneka Cipta. 2005. Hal. 56

${ }^{10}$ Djamarah. Op, cit., hal. 12.

11 Tobroni. Pendidikan Islam: Paradigma Teologis, Filosofis, dan Spiritualitas. Malang. UMM Press. 2008, hal. 144-145.

12 Ibid.

13 Ibid. 
dan sebagainya, melainkan membangun dan membangkitkan keimanan, jiwa agama, karakter dan kepribadian.

Interaksi edukatif harus bermakna interaksi dari hati ke hati, mencerahkan hati nurani, dan membangun jiwa. Guru dalam interaksi edukatif berperan sebagai penyalur dan sarana hidayah Tuhan kepada anak didik agar mereka mendapatkan petunjuk, bimbingan, dan pencerahan. ${ }^{14}$

2. Head, yang meliputi kerangka berfikir dan peta mental (mindset) dan Pengetahuan (knowledge)

Peran guru dalam interaksi edukatif, bukan hanya menyampaikan mata pelajaran semata (transfer of knowledge), melainkan lebih dari itu. Guru harus mampu membangun mindset, yaitu pola pikir ilmiah (objektif, kritis, analitis, berani, dan terbuka), dan membangun karakter.

3. Hand, yang meliputi tindakan (action) dan prilaku (behavior)

Melalui proses interaksi edukatif, guru tidak hanya melatih anak didik untuk melakukan suatu perbuatan dan membentuk prilaku, tetapi juga harus jadi motivator, penggerak dan suri tauladan.

\section{Metode Penelitian}

Penelitian ini adalah penelitian kualitatif. Sedangkan jenis penelitian yang peneliti gunakan adalah studi pustaka (Library Reseacrh). Studi kepustakaan adalah teknik pengumpulan data dengan mengadakan studi penelaahan terhadap buku-buku, literatur-literatur, catatat-catatan, dan laporan-laporan yang ada hubungannya dengan masalah yang ingin dipecahkan. ${ }^{15}$ Dalam pengertian ini peneliti mengumpulkan data-data dari sumber-sumber tertulis baik berupa buku-buku, artikel, karangan ilmiah, dan sumber-sumber tertulis lain baik melalui media cetak maupun media elektronik. Selanjutnya menganilis data dengan menggunakan metode analisis isi (Content Analysis Method).

\section{Konsep Interaksi Edukatif dalam al-Qur`an}

Pendidikan yang dilakukan oleh Nabi Ya`qub dalam al-Qur`an surah alBaqarah ayat 133 menekankan pada aspek keimanan. Firman Allah:

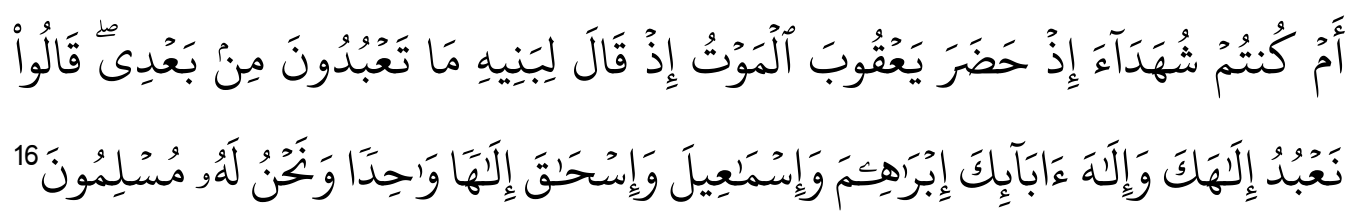

Terjemah:

14 Ibid.

15 M. Nazir. Metode Peneltian. Jakarta. Ghalia Indonesia. 2003. Hal. 111.

16 Al-Quran 
"Adakah kamu hadir ketika Ya'qub kedatangan (tanda-tanda) maut, ketika ia berkata kepada anak-anaknya: "Apa yang kamu sembah sepeninggalku?" Mereka menjawab: "Kami akan menyembah Tuhanmu dan Tuhan nenek moyangmu, Ibrahim, Ismail dan Ishaq, (yaitu) Tuhan Yang Maha Esa dan kami hanya tunduk patuh kepada-Nya"

Nabi Ya`qub menekankan aspek keimanan dalam memberikan materi kepada anaknya. Sebagaimana yang diketahui bahwa beliau adalah cucu dari Nabi Ibrahim. Nabi Ya`qub meneruskan wasiat dari kakenya kepada anaknya agar beriman kepada Allah sampai akhir hayatnya (husnul khtimah). Pada saat menjelang kematiannya, beliau meminta kejelasan kepada anaknya tentang apa yang akan mereka sembah sepeninggalnya, dan anaknya menjawab dengan jelas bahwa yang akan mereka sembah adalah Tuhan yang Maha Esa yaitu Tuhan kake mereka Nabi Ibrahim. Dari hal keadaan tersebut, terlihat bahwa Nabi Ya`qub ingin memastikan masa depan anak-anaknya menjadi generasi yang memiliki akidah dan iman yang kuat kepada Allah.

Pendidikan yang dilakukan oleh Nabi Ibrahim kepada anaknya Ismail dalam al-Qur`an surah al-Saffat ayat 102:

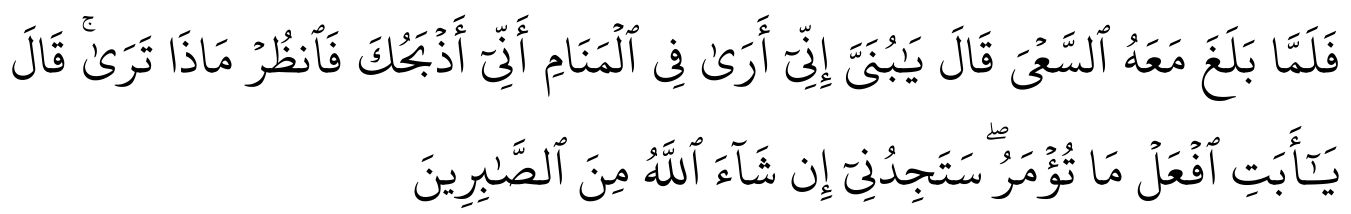

Terjemah:

"Maka tatkala anak itu sampai (pada umur sanggup) berusaha bersamasama Ibrahim, Ibrahim berkata: "Hai anakku sesungguhnya aku melihat dalam mimpi bahwa aku menyembelihmu. Maka fikirkanlah apa pendapatmu!" Ia menjawab: "Hai bapakku, kerjakanlah apa yang diperintahkan kepadamu; insya Allah kamu akan mendapatiku termasuk orang-orang yang sabar"

Perintah penyembelihan tersebut menyangkut tentang hak hidup Ismail. Sehingga untuk melaksanakan perintah penyembelihan itu, maka akan membutuhkan keimanan yang kuat dan juga kematangan emosinal (spiritual). Ismail memiliki keimanan dan kematangan emisoanal sehingga mampu menjalankan perintah dari Allah SWT. tersebut. Ibrahim telah berhasil mendidik anaknya sehingga memiliki keimanan yang kuat sehingga melahirkan dedikasi yang tinggi kepada Tuhan dan juga kepada orang tuanya dengan melaksanakan apa yang diperintahkan Allah.

Nabi Ibrahim memanggil anaknya dengan menggunakan kata “بني", kata "bunayya" adalah bentuk tashghir/perkecilan dari kata ابنى "بنى" (ibni/anakku). Bentuk ini digunakan untuk menggambarkan kasih sayang 
kepada anak. ${ }^{17}$ Pendidikan yang dilakukan Nabi Ibrahim penuh dengan kasih sayang sehingga memberikan pengaruh yang baik terhadap ketercapaian tujuan pendidikan. Selain itu beliau juga memperhatikan aspek kejiwaan dengan memperhatikan usia Ismail saat itu, setelah dianggap siap barulah Ibrahim menyampaikan perintah tersebut. Nabi Ibrahim tidak serta merta menyampaikan saja perintah tersebut kemudian melaksanakannya, melainkan dengan bermusyawarah, meminta pendapat dan keputusan dari Ismail. Hal ini merupakan bentuk demokratis beliau dalam memberikan pelajaran, tidak mendidik dengan cara otoriter melainkan meminta pendapat puteranya. Jika sekiranya saat itu Ismail menolak, maka bukan tidak mungkin pelaksanaan berkurban tidak menjadi sesuatu yang syari atkan.

Pendidikan yang dilakukan oleh Nabi Ibrahim sesuai dengan paradigma pendidikan humanistik yang memandang manusia sebagai "manusia" yaitu ciptaan Tuhan dengan fitrah-fitrahnya. ${ }^{18}$ Pendidikan humanistik memperhatikan kehidupan prilaku seseorang dengan humanis antara lain lebih merespon perasaan, mempertimbangakan gagasan siswa, dan mempunyai keseimbangan teoritik dan praktek. ${ }^{19}$

Pendidik atau guru merupakan salah satu komponen penting dalam proses interaksi edukatif. Seorang guru memiliki peranan besar dalam mendidik, sehingga harus memiliki berbagai kompotensi-kompotensi dalam melaksanakan tugasnya sebagai pendidik. Pada ayat-ayat yang dikaji, dari proses pendidikan yang dilakukan oleh Nabi Ibrahim dan Nabi Ya`qub, dapat terlihat beberapa sikap (kompetensi) yang dimiliki para pendidik tersebut, yaitu sabar, penyayang, demokratis, mengaketahui kondisi psikologis murid, menguasai materi, sabar, dan ikhlas.

\section{PENUTUP}

Hasil penelitian menunjukan bahwa interaksi edukatif dalam al-Qur`an memiliki tujuan menciptakan generasi yang bertauhid kepada Allah, rajin beribadah, dan berakhlak yang mulia. Ketercapaian tujuan itu dipengaruhi oleh kepribadian seorang pendidik yang sabar, penyayang, dan mengetahui kondisi psikologis murid. Interaksi edukatif dalam al-Qur`an merupakan jembatan penghubung antara hati/nilai (velues), pengetahuan (knoeledge), dan perbuatan (behavior) yang mengantarkan peserta didik menjadi sosok yang tercerahkan, mampu membangun mindset, yaitu pola pikir ilmiah dan memiliki karakter yang mulia.

17 Qurais Shihab. Tafsir al-Mishbah Pesan, Kesan, dan Keserasian al-Qur`an. Jakarta. Lentera Hati. 2006, Vol. VI, hal 258.

${ }^{18}$ Intan. Konsep Pendidikan Humanistik Ki Hajar Dewantara dalam Pandangan Islam. Semarang. Tesis Pascasarjana IAIN Walisongo. 2012. Hal. 13.

19 Ibid. hal. 12 


\section{Daftar Pustaka}

Al-Quran al-Karim

Djamarah (2000). Guru dan Anak Didik dalam Interaksi Edukatif. Jakarta. PT. Rinneka Cipta.

Intan. (2012). Konsep Pendidikan Humanistik Ki Hajar Dewantara dalam Pandangan Islam. Semarang. Tesis Pascasarjana IAIN Walisongo.

Makmun. (2004). Psikologi Kependidikan Perangkat Sistem Pengajaran Modul. Bandung. PT. Remaja Rosdakarya.

Nazir, M. (2003). Metode Peneltian. Jakarta. Ghalia Indonesia.

Tafsir, Ahmad. (2008). Filsafat Pendidikan Islami: Integrasi Jasmani, Rohani, dan Kalbu Memanusiakan Manusia. Bandung. PT. Remaja Rosda Karya.

Tirtaraharja, Umar. (2005). Pengantar Pendidikan. Jakarta. PT. Rinneka Cipta.

Tobroni. (2008). Pendidikan Islam: Paradigma Teologis, Filosofis, dan Spiritualitas. Malang. UMM Press.

Sardiman. (2007). Interaksi dan Motivasi Belajar Mengajar. Jakarta. PT. Raja Grafindo Persada.

Shihab, Qurais. (2006). Tafsir al-Mishbah Pesan, Kesan, dan Keserasian alQur'an. Jakarta. Lentera Hati. Vol. VI. 